Article

\title{
Antioxidant Rich Extracts of Terminalia ferdinandiana Inhibit the Growth of Foodborne Bacteria
}

\author{
Saleha Akter ${ }^{1}$ (D), Michael E. Netzel ${ }^{1}$, Ujang Tinggi ${ }^{2}$, Simone A. Osborne ${ }^{3}$, Mary T. Fletcher ${ }^{1}$ (i) \\ and Yasmina Sultanbawa $1, * \mathbb{D}$ \\ 1 Queensland Alliance for Agriculture and Food Innovation (QAAFI), The University of Queensland, Health \\ and Food Sciences Precinct, 39 Kessels Rd, Coopers Plains, QLD 4108, Australia \\ 2 Queensland Health Forensic and Scientific Services, 39 Kessels Rd, Coopers Plains, QLD 4108, Australia \\ 3 CSIRO Agriculture and Food, 306 Carmody Road, St Lucia, QLD 4067, Australia \\ * Correspondence: y.sultanbawa@uq.edu.au; Tel.: +617-344-32471
}

Received: 26 June 2019; Accepted: 20 July 2019; Published: 24 July 2019

check for updates

\begin{abstract}
Terminalia ferdinandiana (Kakadu plum) is a native Australian plant containing phytochemicals with antioxidant capacity. In the search for alternatives to synthetic preservatives, antioxidants from plants and herbs are increasingly being investigated for the preservation of food. In this study, extracts were prepared from Terminalia ferdinandiana fruit, leaves, seedcoats, and bark using different solvents. Hydrolysable and condensed tannin contents in the extracts were determined, as well as antioxidant capacity, by measuring the total phenolic content (TPC) and free radical scavenging activity using the 2, 2-diphenyl-1-picrylhydrazyl (DPPH) assay. Total phenolic content was higher in the fruits and barks with methanol extracts, containing the highest TPC, hydrolysable tannins, and DPPH-free radical scavenging capacity $(12.2 \pm 2.8 \mathrm{~g} / 100 \mathrm{~g}$ dry weight (DW), $55 \pm 2 \mathrm{mg} / 100 \mathrm{~g}$ DW, and 93\% respectively). Saponins and condensed tannins were highest in bark extracts $(7.0 \pm 0.2$ and $6.5 \pm 0.7 \mathrm{~g} / 100 \mathrm{~g} \mathrm{DW})$. The antimicrobial activity of extracts from fruit and leaves showed larger zones of inhibition, compared to seedcoats and barks, against the foodborne bacteria Listeria monocytogenes, Bacillus cereus, Methicillin resistant Staphylococcus aureus, and clinical isolates of Pseudomonas aeruginosa. The minimum inhibitory concentration and minimum bactericidal concentration in response to the different extracts ranged from 1.0 to $3.0 \mathrm{mg} / \mathrm{mL}$. Scanning electron microscopy images of the treated bacteria showed morphological changes, leading to cell death. These results suggest that antioxidant rich extracts of Terminalia ferdinandiana fruits and leaves have potential applications as natural antimicrobials in food preservation.
\end{abstract}

Keywords: Kakadu plum; Terminalia ferdinandiana; antioxidants; antimicrobial activity; food preservation; phytochemicals; polyphenols

\section{Introduction}

Antioxidants from plants and herbs are progressively being used as alternatives to synthetic antioxidants (like butylated hydroxyanisole, butylated hydroxytoluene, and propyl gallate) to preserve food [1]. The use of synthetic antioxidants is tightly regulated due to the health risks such as potential organ toxicity and carcinogenicity associated with overuse [2]. In addition to being used as natural food preservatives, the use of plant antioxidants as functional food ingredients and/or supplements is also growing, based on new findings regarding their potential biological activities [3]. In particular, plant phytochemicals have received substantial research attention based on their ability to act as reducing agents, hydrogen donors, and singlet and triplet oxygen quenchers [4]. Food safety is an important international concern, as food spoilage, due to bacteria and fungi, causes considerable economic loss worldwide [5]. Due to recent outbreaks of emerging pathogens, such as Listeria monocytogenes, 
and rising worldwide impacts of foodborne illness, consumer concerns over food safety and food formulation have increased [1,5], along with the demand for non-toxic natural food preservatives [5]. Many plant extracts possess antimicrobial activity, however inherent variations in bioactivity and concentration places some limitations on the use of plant extracts in food products [6]. However, plant phytochemicals, such as polyphenols, alkaloids, and polypeptides, are known to retain the microbiological and chemical quality of fresh and processed foods [7].

Terminalia ferdinandiana Exell., commonly called Kakadu plum, billy goat plum, gubinge, or salty plum, is a native flowering Australian plant from the Combretaceae family [8]. This endemic Australian, semi-deciduous plant grows in the tropical rangelands of the Northern territory, the Kimberley area of Western Australia, and in some northern parts of Queensland (Figure 1) [9,10]. The fruits are smooth-skinned, fleshy ovoid drupes with a short beak that become yellow-green when ripe (Figure 1). There are about 250 species of the genus Terminalia from the family Combretaceae growing in tropical regions across the globe [11]. Among them, approximately 30 species or subspecies of Terminalia are endemic to Australia $[9,10]$. A high degree of phytochemical variability exists amongst different species and subspecies due to genetic diversity, soil and climate conditions, fruit ripening stage, storage, and other post-harvest conditions [12].

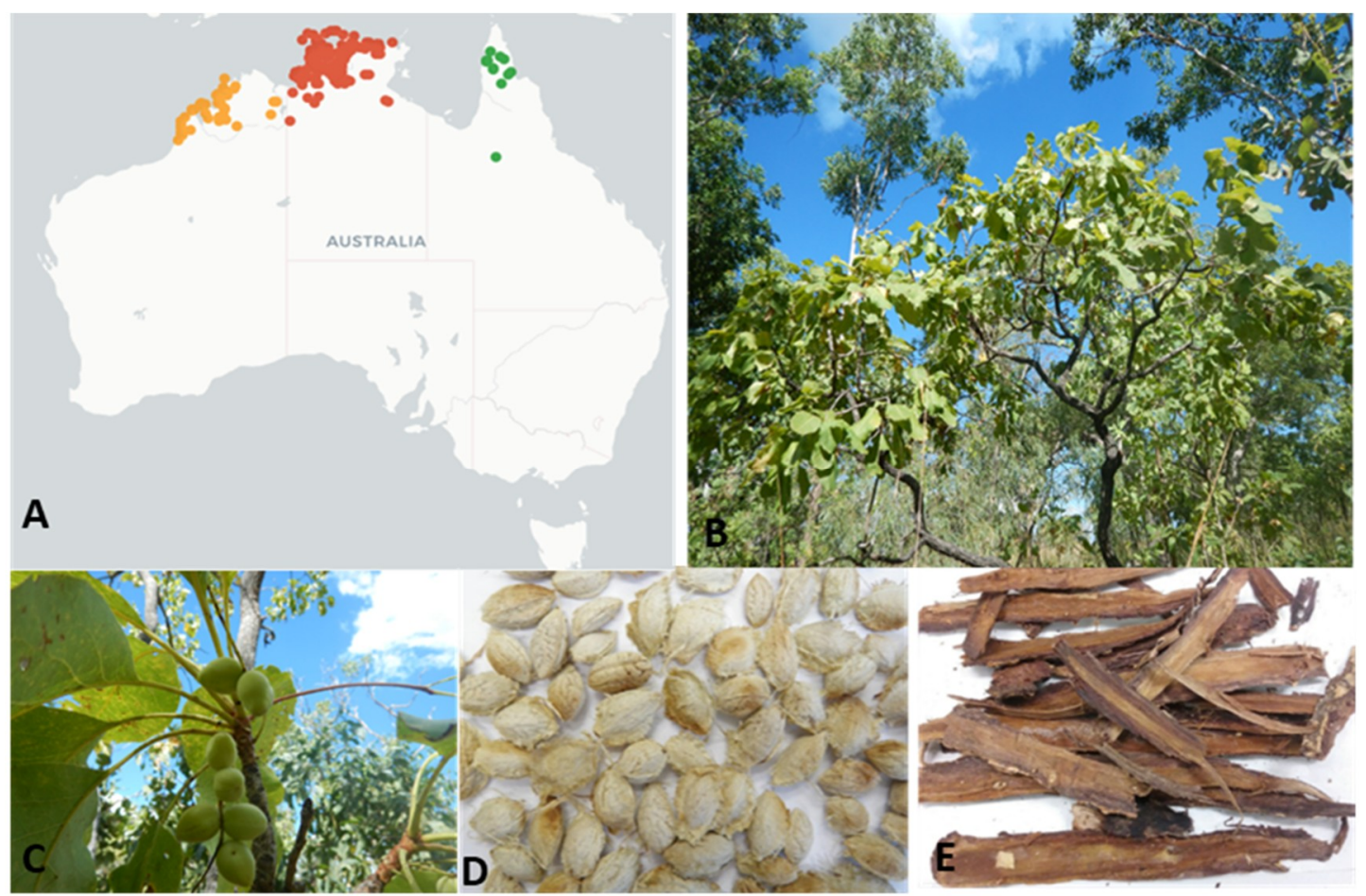

Figure 1. (A) Distribution of Terminalia ferdinandiana from the Australasian Virtual Herbarium website. (https://avh.ala.org.au) showing • West Australian, @ Northern Territory and @ Queensland locations.

(B) Mature tree; (C) leaves and fruits; (D) seeds; and (E) bark.

Due to increasing commercial demand from local and international food industries, T. ferdinandiana products are often stored for long periods. Subsequently, the bioactivity and safety of these products must be ensured following long-term storage. A study by Sultanbawa et al. [13] investigated the safe storage of $T$. ferdinandiana extracts and not only confirmed the retention of bioactivity over a period of 18 months in frozen storage $\left(-20^{\circ} \mathrm{C}\right)$, but also identified chemical markers for determining the end-of-storage life of T. ferdinandiana extracts.

Studies focused on the bioactivities of the various phytochemicals in T. ferdinandiana fruit and leaves have identified ellagic acid, gallic acid, ethyl gallate, chebulic acid, corilagin, hydroxycinnamic acid, ascorbic acid, $\alpha$-tocopherol, lutein, tannins, chebulagic acid, exifone, punicalin, castalagin, 
appanone A-7 methyl ether, xanthotoxin, and phthalane [14-16]. The objective of the present study was to determine the potential of T. ferdinandiana extracts as antioxidants and antimicrobial agents in food preservation.

\section{Materials and Methods}

\subsection{Chemicals}

Methanol anhydrous (99.8\%), ethyl alcohol (pure), acetone (HPLC grade $\geq 99.9 \%$ ), n-hexane (99\%), Folin-Ciocalteu's phenol reagent, gallic acid monohydrate (American Chemical Society (ACS) reagent), 2, 2-Diphenyl-1-picrylhydrazyl (DPPH), n-butanol anhydrous (99.8\%), potassium phosphate tribasic (regent grade $\geq 98 \%$ ), vanillin, sulfuric acid (99.9\%), saponin from Quillaja bark (sapogenin content $\geq 10 \%$ ), potassium iodate (99.7-100.4\%), tannic acid, and catechin analytical standard were obtained from Sigma-Aldrich (Castle Hill, New South Wales, Australia). Sodium carbonate anhydrous was obtained from Chem-supply, Bedford St, Gillman, South Australia, AU; chloroform (high purity solvent) and trolox were obtained from Merck KGaA, Darmstadt, Germany; $\mathrm{HCl}$ (Trace metal grade) was obtained from Fisher Scientific, United States Fisher HealthCare, Veterans Memorial Dr. Houston, Texas, USA. Standard plate count agar (American Public Health Association) (PCA) (CM0463), potato dextrose agar (PDA) (CM 0139), nutrient broth (CM 001), and tryptone soya yeast extract broth (TYSEB) (CM 129B) were purchased from Oxoid Ltd, Basingstoke, UK. Grade AA (6 mm) discs were purchased from GE Healthcare Life Sciences, Whatman, UK.

\subsection{Sample Collection and Processing}

Ripe and mature fruits of T. ferdinandiana (total harvest of $5000 \mathrm{~kg}$ ) were collected from over 600 trees, from native bushland covering a land area of $20,000 \mathrm{~km}^{2}$ in the Northern Territory, Australia, in 2015. A voucher specimen, AQ522453, was deposited at the Queensland Herbarium. A portion of the collected fruits were processed by Sunshine Tropical Fruit Products, Nambour, Queensland, Australia, to provide a seedless puree, along with the separated seeds, which were stored at $-80^{\circ} \mathrm{C}$ until further analysis. The puree was then freeze-dried and milled to provide a uniform powder that was stored at $-20^{\circ} \mathrm{C}$ and used throughout this study. The freeze-dried puree will be referred to as fruits/fruit extract. The frozen seeds were thawed and washed several times with double distilled water to remove the pulp residue. The seeds were then oven-dried for $48 \mathrm{~h}$ at $40{ }^{\circ} \mathrm{C}$. After drying, the seeds were individually cracked using an Engineers vice size 125 (DAWN tools and Vices Pty Ltd, Heidelberg West, Victoria, Australia) to release the kernels from the seedcoats. The seedcoats were processed and analyzed separately in a previous study [17]. The separated seedcoats were hammer milled and used for this study. Leaves and bark were also collected from the same region during the same fruit harvest and were freeze-dried and milled. The milled freeze-dried powders of leaves and bark were used throughout this study.

\subsection{Preparation of Kakadu Plum Extracts}

Accelerated solvent extraction (ASE) (Dionex ASE 200 system, Dionex Corp., Sunnyvale, CA, USA) was performed to prepare the extracts for antioxidant and antimicrobial assays [18]. Briefly, $10 \mathrm{~mL}$ stainless steel extraction cells were assembled and fitted with a $27 \mathrm{~mm}$ cell filter at the bottom end. Aliquots $(1.0 \mathrm{~g})$ of freeze-dried powders of fruits and leaves, and dried powders of seedcoats of T. ferdinandiana were mixed with diatomaceous earth (approximately four to five times the weight of the powders to fill the cells completely) and placed in the cells. Five different solvents were used: methanol, ethanol, acetone, hexane, and distilled water. The ASE unit was operated under the following conditions: $60^{\circ} \mathrm{C}$ for methanol and ethanol, $50{ }^{\circ} \mathrm{C}$ for acetone and hexane, and $75^{\circ} \mathrm{C}$ for distilled water; preheat $5 \mathrm{~min}$; static time $5 \mathrm{~min}$, eight extraction cycles, rinse volume $25 \%$ with fresh extraction solvent; and purged with $150 \mathrm{psi}$ for $60 \mathrm{sec}$. The cells containing the samples were prefilled with the respective extraction solvent, pressurized, and heated with the extracts collected into $60 \mathrm{~mL}$ amber glass vials. 
MiVac sample concentrator (GeneVac Inc., New York, NY, USA) was used to concentrate and dry the extracts. The temperatures for solvent evaporation were controlled as follows: methanol and ethanol extracts at $50{ }^{\circ} \mathrm{C}$, acetone and hexane extracts at $45^{\circ} \mathrm{C}$, and water extracts at $70^{\circ} \mathrm{C}$. The concentrated extracts were weighed and stored at $-20{ }^{\circ} \mathrm{C}$ until analysis.

\subsection{Antioxidant Capacity}

\subsubsection{Total Phenolic Content}

The total phenolic content (TPC) of the various solvent extracts of T. ferdinandiana tissues was determined by spectrometry using the Folin-Ciocalteu reagent [19]. The extracts $(25 \mu \mathrm{L})$ were added to the 96-well plate and $125 \mu \mathrm{L}$ freshly prepared Folin-Ciocalteu reagent and $125 \mu \mathrm{L}$ sodium carbonate $(7.5 \% w / v)$ were also added to the wells. The mixture was incubated in the dark for $30 \mathrm{~min}$ at room temperature. Absorbance was measured at $750 \mathrm{~nm}$ using a Tecan Microplate Reader (Tecan Infinite M200, Tecan Trading AG, Mannedorf, Switzerland) with Magellan Software (version 6.4, Tecan Trading AG). Results were expressed as g gallic acid equivalents (GAE)/100 g dry weight (DW).

\subsubsection{DPPH Radical Scavenging Activity}

The DPPH radical scavenging activity assay was performed as per the previously described method [19]. Methanol $(200 \mu \mathrm{L})$ was used as blank. Control wells contained $100 \mu \mathrm{L}$ of methanol and $100 \mu \mathrm{L}$ of DPPH $(0.15 \mathrm{mM})$. Samples $(100 \mu \mathrm{L})$ and $100 \mu \mathrm{L}$ of DPPH $(0.15 \mathrm{mM})$ were added to the appropriate wells. The plates were shaken for $15 \mathrm{sec}$ and incubated for $40 \mathrm{~min}$ at room temperature and were kept in the dark. Trolox standards at different concentrations $(5-35 \mu \mathrm{M} / \mathrm{L})$ were treated as samples. Absorbance was measured at $517 \mathrm{~nm}$ using a Tecan Microplate Reader with the percentage radical scavenging activity of each extract calculated from the standard curve, using the formula described previously [20]; Percentage of radical scavenging activity $=\left(\right.$ Control $\left._{\mathrm{Abs}}-\mathrm{Sample}_{\mathrm{Abs}} / \mathrm{Control}_{\mathrm{Abs}}\right)$ $\times 100 \%$.

\subsection{Determination of Total Saponin Content}

Saponin extracts were prepared as previously described by $\mathrm{Xi}$, et al. [21], with modifications. Briefly, $0.5 \mathrm{~g}$ powdered T. ferdinandiana fruits, leaves, seedcoats, and barks were extracted three times with $80 \%$ ethanol at a ratio of 1:10 w/v under reflux at $80{ }^{\circ} \mathrm{C}$ for $1 \mathrm{~h}$. The combined alcohol extract was concentrated, suspended in distilled water, and then partitioned successively with chloroform (ratio 1:3 $v / v$ ) and n-butanol saturated with water (ratio 1:3 v/v, three times). The n-butanol extract was combined and evaporated using a rotary evaporator at $60^{\circ} \mathrm{C}$ to give a solid residue. Prior to the assay, the extracts were solubilized in $0.5 \mathrm{M}$ phosphate buffer ( $\mathrm{pH}$ 7.4). The total saponin content of each extract was determined using the method described by $\mathrm{Xi}$ et al. [21]. The extracts $(50 \mu \mathrm{L})$ were mixed with $500 \mu \mathrm{L}$ of vanillin $(8 \% w / v)$ and $5 \mathrm{~mL}$ of sulphuric acid $(72 \% w / v)$. The mixture was then incubated for $10 \mathrm{~min}$ at $60^{\circ} \mathrm{C}$ and cooled in an ice water bath for $15 \mathrm{~min}$. The absorbance was read at $538 \mathrm{~nm}$. Saponin from quillaja bark was used as a reference standard, with the total saponin content of each extract expressed as g quillaja saponin equivalents (QSE)/100 g DW).

\subsection{Determination of Condensed Tannin Content}

The condensed tannins in the T. ferdinandiana tissues were determined using the vanillin/ $\mathrm{HCl}$ assay described by Ahmed, et al. [22]. The extract $(500 \mu \mathrm{L})$ was mixed with $3 \mathrm{~mL}$ of vanillin reagent containing $4 \%$ concentrated $\mathrm{HCl}$ and $0.5 \%$ vanillin in methanol in a $15 \mathrm{~mL}$ falcon tube. The mixture was allowed to stand for $15 \mathrm{~min}$ at room temperature and the absorbance was then recorded at $500 \mathrm{~nm}$. Methanol was used as the blank. An appropriate standard curve was prepared using catechin, with concentrations ranging from 0.02 to $2.5 \mathrm{mg} / \mathrm{mL} \mathrm{w} / \mathrm{v}$. The amount of condensed tannins in the extracts was expressed as g catechin equivalents $(\mathrm{CaE}) / 100 \mathrm{~g}$ DW. 


\subsection{Determination of Hydrolysable Tannin}

The hydrolysable tannins in the T. ferdinandiana tissue extracts were determined using the potassium iodate assay previously described by Hoang, et al. [23]. Briefly, $50 \mu \mathrm{L}$ of $1 \mathrm{mg} / \mathrm{mL} w / v$ extract was added to a 96-well plate with $150 \mu \mathrm{L}$ of $2.5 \% \mathrm{w} / \mathrm{v}$ potassium iodate. Absorbance was measured at $550 \mathrm{~nm}$ after $15 \mathrm{~min}$, using a Tecan Microplate Reader (Tecan Infinite M200) with Magellan Software (version 6.4). Tannic acid was used as a standard and results were expressed as mg tannic acid equivalents (TAE)/100 g DW.

\subsection{Antimicrobial Activity}

\subsubsection{Foodborne Microorganisms}

Foodborne microorganisms, including pathogenic and clinical isolates, were chosen for this study. A total of $4 \mathrm{~g}$ positive bacteria-Staphylococcus aureus (NCTC 6571) (National Collection of Type Cultures, Health Protection Agency Centre for Infection, London, UK), methicillin resistant Staphylococcus aureus (MRSA) clinical isolates (CI) (Royal Brisbane and Women's Hospital, Herston, Queensland, AU), Bacillus cereus (ATCC 10876) (Microbiologics Inc., St. Cloud, MN, USA), and Listeria monocytogenes (ATCC 19111) (The University of Queensland, Brisbane, AU)—and $2 \mathrm{~g}$ negative bacteria—Pseudomonas aeruginosa (ATCC 10145) (Microbiologics Inc., St. Cloud, MN, USA), and Pseudomonas aeruginosa clinical isolates (CI) (ATCC 9001) (Royal Brisbane and Women's Hospital, Herston, Queensland, AU) - were tested. Bacteria were maintained on plate count agar (PCA) medium at $4{ }^{\circ} \mathrm{C}$ and sub-cultured on PCA medium at $37^{\circ} \mathrm{C}$ for $24 \mathrm{~h}$.

\subsubsection{Disc Diffusion Assay}

The ASE of fruits, leaves, seedcoats, and barks of T. ferdinandiana were diluted with $20 \%$ ethanol to prepare a final concentration $10 \mathrm{mg} / \mathrm{mL} w / v$ extract, except for the water extracts, which were diluted with reverse osmosis (RO) water. The zone of inhibition was determined using the Kirby-Bauer assay modified by Dussault, et al. [24]. The zone of inhibition was measured using a digital calliper $150 \mathrm{~mm}$ (ALDI, Australia). RO water and $20 \%$ ethanol were used as the negative controls. A standard antibiotic solution, oxytetracycline $(0.06 \mathrm{mg} / \mathrm{mL}$; Sigma-Aldrich, St. Louis, MN, USA), was used as positive control. All experiments were performed in triplicate and the antimicrobial activity was evaluated by measuring the inhibition zones against the tested microorganisms.

\subsubsection{Determination of Minimum Inhibitory Concentration and Minimum Bactericidal Concentration}

The minimum inhibitory concentration (MIC) and minimum bactericidal concentration (MBC) of the extracts were determined by the microplate dilution method [25]. Different concentrations of the extracts were prepared using $20 \%$ ethanol and added to the microtiter wells to obtain final concentrations of $4,3.5,3,2.5,2,1.5,1$, and $0.5 \mathrm{mg} / \mathrm{mL}$. Nutrient broth (NB) $(200 \mu \mathrm{L})$ was used as a control to ensure the broth was sterile, whilst $50 \mu \mathrm{L}$ bacterial culture $\left(1 \times 10^{5}\right.$ colony forming unit $(\mathrm{CFU}) / \mathrm{mL}$, as determined by colony counting after serial dilution and plating) and $150 \mu \mathrm{L}$ nutrient broth were used as the negative control. Aliquots $(100 \mu \mathrm{L})$ of extracts $(1-8 \mathrm{mg} / \mathrm{mL})$ were added to a 96-well microplate. A total of $50 \mu \mathrm{L}$ bacterial culture and $50 \mu \mathrm{L} \mathrm{NB}$ were also added to the wells to make the final volume $200 \mu \mathrm{L}$. Six replicates were prepared for each concentration of the extracts and the positive antibiotic control solution $(0.0625 \mathrm{mg} / \mathrm{mL}$ oxytetracycline). The microplates were incubated at $37^{\circ} \mathrm{C}$ with visual observation of bacterial growth performed after $24 \mathrm{~h}$. The MIC values were identified as the minimum concentration at which no visible bacterial growth was recorded [18]. The MBC was observed as the lowest concentration that completely inhibited the bacteria. A $50 \mu \mathrm{L}$ aliquot from all wells showing no visible bacterial growth in the MIC assay [26] was applied to PCA plates and incubated at $37^{\circ} \mathrm{C}$ for $24 \mathrm{~h}$. The MBCs of the extracts were measured by observing the viability of the initial bacterial inoculum. 


\subsubsection{Scanning Electron Microscopy}

The methicillin resistant S. aureus, clinical isolates of P. aeruginosa, L. monocytogenes, and B. Cereus strains were grown for $7 \mathrm{~h}$ in tryptone soya yeast extract broth (TSYEB) at $37^{\circ} \mathrm{C}$. Methanolic ASE of T. ferdinandiana fruits and leaves were reconstituted in $75 \mu \mathrm{L} \mathrm{20 \%} v / v$ ethanol, added to $1 \mathrm{~mL}$ bacteria and broth samples, and incubated for $24 \mathrm{~h}$ at $37^{\circ} \mathrm{C}$. The negative control was comprised of $75 \mu \mathrm{L} 20 \%$ $v / v$ ethanol. The samples and controls were washed three times in sterile phosphate buffered saline and fixed in 3\% v/v glutaraldehyde [27]. Glutaraldehyde-fixed samples were fixed again in $1 \% v / v$ osmium tetroxide and dehydrated with ethanol. Samples were adhered to coverslips coated with poly-L-lysine $(1 \mathrm{mg} / \mathrm{mL})$ and dehydrated in the same manner, before being dried in a critical point dryer (Tousimis Research Corporation, Rockville, MD, USA) according to manufacturer's instructions. Coverslips were attached to stubs with double-sided carbon tabs and coated with gold using a sputter coater (Agar Scientific Ltd, Essex, UK), following the manufacturer's instructions. Samples were imaged in a Jeol Neoscope JCM 5000 (Jeol Ltd., Tokyo, Japan) at an accelerating voltage of $10 \mathrm{kV}$ and for high resolution images in a Jeol JSM 7100F (Jeol Ltd., Tokyo, Japan) field emission scanning electron microscopy (SEM) at an accelerating voltage of $1 \mathrm{kV}$.

\subsection{Statistical Analysis}

All values were expressed as mean $\pm \mathrm{SD}(n=3)$. Statistical analysis of the results was performed using two-way ANOVA, followed by Tukey's multiple comparison post hoc tests, with significant differences observed at $p<0.05$ using GraphPad Prism version 8 (La Jolla, CA, USA).

\section{Results and Discussion}

\subsection{Extraction Yields}

The ASE yields from the T. ferdinandiana tissues are presented in Figure 2 and vary depending upon the plant tissue and solvent used. The yield variations observed from the same tissues following different ASE methods could be attributed to the varying polarities of compounds present in the various tissues [1]. A yield of $45 \%$ was achieved from fruit and bark powders using methanol extraction, whilst ethanol produced extract yields of $59 \%$ and $26 \%$ from barks and fruit powders, respectively. Water extraction produced similar yields from fruits, leaves, and barks, ranging from $30-40 \%$. Acetone and hexane produced comparatively lower extract yields to other solvents, except from leaves, where acetone produced an extract yield similar to ethanol. The variable yields achieved by the different ASE methods could be due to the solubility of the phytochemicals in the different tissues, as well as the duration, temperature, and $\mathrm{pH}$ of the extraction conditions, along with the particle size of the sample and the solvent-to-sample ratio [28].

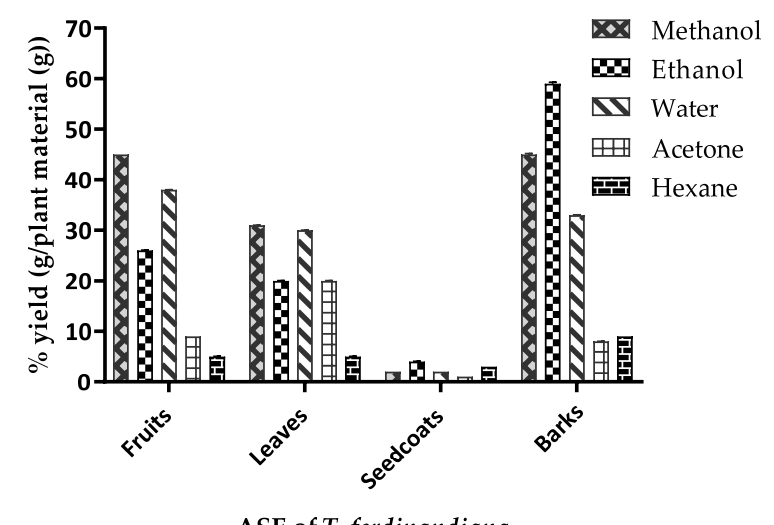

ASE of T. ferdinandiana

Figure 2. Yield (\%) of the accelerated solvent extraction (ASE) of Terminalia ferdinandiana. Results are shown as the mean of triplicate experiments \pm SD. 


\subsection{Antioxidant Capacity}

\subsubsection{Total Phenolic Content}

The total phenolic contents (TPC) of all extracts are presented in Table 1 and ranged from 0.04-24 g GAE/100 g DW. In the T. ferdinandiana fruits extracts, TPC ranged from 0.38-12 g/100 g DW. The barks and leaves also contained high TPC, ranging from 0.04-2 g/100 g DW. The highest TPC was measured in methanol ASE from the fruit and leaves, followed by ethanol $>$ acetone $>$ water $>$ hexane. In the bark ASE, ethanol produced the highest TPC, followed by methanol $>$ water $>$ acetone $>$ hexane. The seedcoat extracts produced the lowest TPC overall, however had similar trends to the bark extracts, with ethanol $>$ methanol $\approx$ water $>$ acetone $>$ hexane.

Table 1. Total phenolic contents in T. ferdinandiana tissues.

\begin{tabular}{ccccc}
\hline & \multicolumn{4}{c}{ Total Phenolic Content (GAE g/100 g DW) } \\
\hline & Fruits & Leaves & Seedcoats & Barks \\
\hline Methanol & $12.2 \pm 2.9^{\mathrm{a}, \mathrm{w}}$ & $11.7 \pm 0.5^{\mathrm{a}, \mathrm{w}}$ & $0.2 \pm 0.0^{\mathrm{x}}$ & $18.0 \pm 2.0^{\mathrm{a}, \mathrm{y}}$ \\
Ethanol & $11.6 \pm 1.0^{\mathrm{a}, \mathrm{w}}$ & $8.8^{\mathrm{b}} \pm 0.5^{\mathrm{b}, \mathrm{x}}$ & $0.3 \pm 0.0^{\mathrm{y}}$ & $23.5 \pm 0.5^{\mathrm{b}, \mathrm{z}}$ \\
Water & $5.2 \pm 0.2^{\mathrm{b}, \mathrm{w}}$ & $4.2 \pm 0.4^{\mathrm{b}, \mathrm{c}, \mathrm{x}}$ & $0.2 \pm 0.0^{\mathrm{y}}$ & $6.7 \pm 0.2^{\mathrm{c}, \mathrm{w}}$ \\
Acetone & $8.0 \pm 0.2^{\mathrm{b}, \mathrm{w}}$ & $5.2 \pm 0.2^{\mathrm{c}, \mathrm{w}}$ & $0.1 \pm 0.0^{\mathrm{x}}$ & $3.5 \pm 0.0^{\mathrm{d}, \mathrm{z}}$ \\
Hexane & $0.4 \pm 0.0^{\mathrm{c}}$ & $0.2 \pm 0.0^{\mathrm{d}}$ & ND & $0.04 \pm 0.0^{\mathrm{e}}$
\end{tabular}

Results are expressed as mean $\pm \mathrm{SD} ;(n=3)$. Mean values of each column with different letters are significantly different (at $p<0.05)$. a, b, c, d, e; denote significant differences of extraction solvents within same tissue. $\mathrm{w}, \mathrm{x}, \mathrm{y}, \mathrm{z}$; denote significant differences of the same extraction solvent across tissues.

The variation in TPC observed in the different extracts could be due to the variable solubility of polyphenols in different solvents, as well as the complex structure of the cellular macromolecules within different plant tissues. The enrichment of phenolic compounds in the extracts also depended on the solvent and the process of extraction [29]. For example, it is possible that hexane primarily extracted non-polar components, such as chlorophyll, waxes, and terpenoids from the tissues producing the lowest TPC. Regardless of the method used to prepare extracts from the different T. ferdinandiana tissues, the TPC content in the extracts indicates enrichment with phenolic compounds, which are potent scavengers of free radicals in vitro, and are believed to provide in vivo antioxidant protection against biomolecule damage and peroxidation of cellular membranes [30].

\subsubsection{DPPH radical Scavenging Capacity}

2, 2-diphenyl-1-picrylhydrazyl (DPPH) is a stable free radical widely accepted as a tool for estimating the free radical-scavenging capacity of an antioxidant. The effect of an antioxidant on DPPH radical scavenging is determined by the ability of the antioxidant to donate hydrogen [31]. The ASE extracts of T. ferdinandiana tissues were assayed for DPPH radical scavenging capacity. Results are presented in Table 2, showing that ASE extracts from the different tissues produced similar results, except for hexane ASE, which showed very low radical scavenging activity. Plant antioxidants are mostly water-soluble and present as glycosides located in the cell vacuole [32]. This is consistent with the findings in Table 2, where polar solvents produced extracts with greater antioxidant potential than non-polar solvents. 
Table 2. The 2, 2-diphenyl-1-picrylhydrazyl (DPPH) radical scavenging capacity of T. ferdinandiana tissues.

\begin{tabular}{|c|c|c|c|c|}
\hline \multirow[b]{2}{*}{$\begin{array}{l}\text { Accelerated solvent extracts } \\
\text { (ASE) of T. ferdinandiana }\end{array}$} & \multicolumn{4}{|c|}{ DPPH Radical Scavenging Activity (\%) } \\
\hline & Fruits & Leaves & Seedcoats & Barks \\
\hline Methanol & $93.4 \pm 0.3^{a, x}$ & $89.4 \pm 0.5^{a, x}$ & $93.0 \pm 0.2^{a, x}$ & $84.7 \pm 0.1^{\mathrm{a}, \mathrm{y}}$ \\
\hline Ethanol & $94.3 \pm 0.1^{\mathrm{a}, \mathrm{x}}$ & $91.8 \pm 0.2^{a, y}$ & $88.0 \pm 0.2^{b, y}$ & $85.8 \pm 0.2^{a, z}$ \\
\hline Water & $93.7 \pm 0.2^{a, x}$ & $84.0 \pm 0.5^{b, y}$ & $90.9 \pm 0.2^{b, x}$ & $79.6 \pm 0.2^{b, y}$ \\
\hline Acetone & $91.5 \pm 0.4^{\mathrm{a}, \mathrm{w}}$ & $79.2 \pm 0.3^{c, x}$ & $74.2 \pm 0.3^{c, x}$ & $85.5 \pm 0.3^{a, y}$ \\
\hline Hexane & $12.9 \pm 0.9^{b, w}$ & $68.7 \pm 0.4^{\mathrm{d}, \mathrm{x}}$ & $2.1 \pm 1.3^{\mathrm{d}, \mathrm{y}}$ & $77.5 \pm 3.8^{\mathrm{b}, \mathrm{z}}$ \\
\hline
\end{tabular}

Results are expressed as mean $\pm \mathrm{SD} ;(n=3)$. Mean values of each column with different letters are significantly different (at $p<0.05$ ). a, b, c, d; denote significant differences of extraction solvents within same tissue. $\mathbf{w}, \mathbf{x}, \mathrm{y}, \mathrm{z}$; denote significant differences of the same extraction solvent across tissues.

\subsection{Determination of Total Saponins}

Saponins are bitter tasting, water-soluble triterpenoids found in various plants. Saponins have been found to possess in vitro anti-inflammatory activities [33], however the bitter taste may limit applications when present in higher quantities. The increased consumer demand for natural products with beneficial physicochemical and biological properties makes steroidal and triterpenoid saponins promising compounds for industrial applications [34]. The major sugar moieties of saponins are glucose, arabinose, galactose, glucuronic acid, xylose, and rhamnose [35]. Saponin-containing plants used for human consumption include soybeans, pulses, peas, chickpea, lentils, oats, potatoes, pepper, tomatoes, onions, garlic, tea, asparagus, cucumber, pumpkins, squash, gourds, melons, watermelons, sugar beet, yam, sunflower, and cassava [36,37]. The saponin content of lentils ranges from 3.7 to $4.6 \mathrm{~g} / \mathrm{kg}$, green peas $11 \mathrm{~g} / \mathrm{kg}$, chickpeas $60 \mathrm{~g} / \mathrm{kg}$, oats $1 \mathrm{~g} / \mathrm{kg}$ and spinach $47 \mathrm{~g} / \mathrm{kg}$ DW [37]. The saponin contents of $T$. ferdinandiana tissues are presented in Table 3 . The slightly bitter taste of $T$. ferdinandiana fruits might be due to the presence of low amounts of saponins. Barks were highest in saponins, whereas no saponins could be detected in the seedcoats.

\subsection{Determination of Condensed and Hydrolysable Tannins}

Tannins are higher molecular weight polyphenolics, found mostly in plants used as food and feed [38]. Tannins are usually divided into two groups-hydrolysable and condensed tannins. The degree of tannin polymerization has been found to directly correlate with radical scavenging capacity $[39,40]$. The antioxidant effects of tannins are mostly attributed to free radical scavenging capacity, chelation of transition metals, inhibition of pro-oxidative enzymes, and lipid peroxidation [39]. Tannins have varying degrees of hydroxylation, and their molecular size is sufficient to form complexes with proteins [41].

Condensed tannin contents of T. ferdinandiana tissues are presented in Table 3, showing that bark has the highest content compared to leaves, which have the lowest content. Fruits were found to contain $0.8 \mathrm{~g}$ condensed tannins $/ 100 \mathrm{~g}$ DW. The hydrolysable tannin contents of $T$. ferdinandiana tissues are shown in Table 4. The hydrolysable tannin content of the tissues ranges between 0.1 and $120 \mathrm{mg} / 100 \mathrm{~g}$ DW of the plant material. Leaves contain more tannins than fruits for all solvent extracts. Very low levels of tannins were observed in all seedcoat extracts, except for the acetone ASE. The highest amount of hydrolysable tannins was found in leaves (Table 4). These results suggest that the level of hydrolysable tannins is greatly influenced by the tissue type, solvents (different polarities), and extraction conditions (Table 4). The results of the present study indicate that tannins in T. ferdinandiana fruit extracts were predominantly condensed tannins.

Using regression analyses, the correlations between TPC, DPPH radical scavenging values, saponin content, and the condensed and hydrolysable tannin content of the fruits, leaves, seedcoats, and barks were explored. The antioxidant capacity and tannin content of the fruits were positively correlated with the antioxidant capacity and tannin content of the leaves (pearson $R^{2}=0.9736, p<0.0001$ ), seedcoats 
(pearson $R^{2}=0.6886, p=0.0001$ ), and barks (pearson $R^{2}=0.7728, p<0.0001$ ). The saponins content of the tissues was positively correlated with the condensed tannins (pearson $R^{2}=0.9922, p<0.05$ ).

Table 3. Saponins and condensed tannins in T. ferdinandiana tissues.

\begin{tabular}{ccc}
\hline T. ferdinandiana Tissues & $\begin{array}{c}\text { Saponin Content } \\
\text { (QSE g/100 g DW) }\end{array}$ & $\begin{array}{c}\text { Condensed Tannin Content } \\
\text { (CaE g/100 g DW) }\end{array}$ \\
\hline Fruits & $0.4^{\mathrm{a}} \pm 0.0$ & $0.8^{\mathrm{a}} \pm 0.1$ \\
Leaves & $0.3 \pm 0.1$ & $0.02^{\mathrm{b}} \pm 0.0$ \\
Seedcoats & $\mathrm{ND}$ & $0.1^{\mathrm{a}} \pm 0.0$ \\
Barks & $7.0^{\mathrm{b}} \pm 0.2$ & $7.0^{\mathrm{c}} \pm 0.7$ \\
\hline
\end{tabular}

Results are expressed as mean $\pm \mathrm{SD} ;(n=3)$. ND = not detected. Mean values of each column with different letters are significantly different $(p<0.05)$.

Table 4. Hydrolysable tannins in T. ferdinandiana tissues.

\begin{tabular}{ccccc}
\hline & \multicolumn{4}{c}{ Hydrolysable Tannin Content (TAE mg/100 g DW) } \\
\hline ASE & Fruits & Leaves & Seedcoats & Barks \\
\hline Methanol & $55.3 \pm 1.6^{\mathrm{a}, \mathrm{w}}$ & $120.8 \pm 2.3^{\mathrm{a}, \mathrm{x}}$ & $0.9 \pm 0.0^{\mathrm{a}, \mathrm{y}}$ & $16.5 \pm 0.2^{\mathrm{a}, \mathrm{z}}$ \\
Ethanol & $33.3 \pm 0.8^{\mathrm{b}, \mathrm{w}}$ & $81.4 \pm 1.4^{\mathrm{b}, \mathrm{x}}$ & $1.42 \pm 0.0^{\mathrm{a}, \mathrm{y}}$ & $20.4 \pm 0.2^{\mathrm{b}, \mathrm{z}}$ \\
Water & $7.5 \pm 0.4^{\mathrm{c}, \mathrm{w}}$ & $52.0^{\mathrm{a}} \pm 0.5^{\mathrm{c}, \mathrm{x}}$ & $1.42 \pm 0.1^{\mathrm{a}, \mathrm{y}}$ & $13.6 \pm 0.0^{\mathrm{c}, \mathrm{z}}$ \\
Acetone & $10.8 \pm 0.7^{\mathrm{d}, \mathrm{w}}$ & $66.5 \pm 1.1^{\mathrm{d}, \mathrm{x}}$ & $27.1 \pm 1.8^{\mathrm{b}, \mathrm{y}}$ & $4.9 \pm 0.0^{\mathrm{d}, \mathrm{z}}$ \\
Hexane & $0.1 \pm 0.1^{\mathrm{e}, \mathrm{w}}$ & $3.1 \pm 0.2^{\mathrm{e}, \mathrm{x}}$ & $2.6 \pm 0.2^{\mathrm{a}, \mathrm{x}}$ & $0.2 \pm 0.4^{\mathrm{e}, \mathrm{w}}$ \\
\hline
\end{tabular}

Results are expressed as mean \pm SD; $(n=3)$. Mean values of each column with different letters are significantly different $(p<0.05)$. a, b, c, d, e; denote significant differences of extraction solvents within same tissue. $w, x, y, z$; denote significant differences of the same extraction solvent across tissues.

\subsection{Antimicrobial Activity}

\subsubsection{Disc Diffusion Assay}

Plant derived antimicrobials can effectively reduce or inhibit pathogenic and spoilage microorganisms and have the potential to be an alternative to synthetic antimicrobials [6]. The use of natural antimicrobial agents in food processing to extend the shelf-life of food products is well documented [6]. Consumer concern over synthetic preservatives in food products has contributed to the search for preservatives from natural sources. The antimicrobial activities of extracts from $T$. ferdinandiana tissues prepared with different solvents were determined against different microorganisms, with the inhibition zone measured in $\mathrm{mm}$, and presented in Table 5 and illustrated in Figure 3. Overall, methanol extracts were found to be the most effective against the organisms tested and showed a broad spectrum of antimicrobial activity against the tested bacteria. The antimicrobial activity of the methanol extracts was similar to the acetone extracts, whilst water extracts from fruit, leaves, and bark were found to be active against S. aureus, MRSA, P. aeruginosa CI, and B. cereus. Fruit and leaf extracts were found to have similar zones of inhibition against the tested organisms, with MRSA, L. monocytogenes, and B. cereus the most sensitive bacteria among those tested. S. aureus was inhibited less compared to MRSA. Seedcoat extracts were found to be the least active against the microorganisms tested.

Herbal remedies formulated from whole plants are gaining more interest, as they are safer than synthetic options. The antimicrobial activity from $T$. ferdinandiana extracts against different microbial strains supports the scientific rationality of using plants/plant tissue in traditional medicine [42]. The inhibition of the growth of six bacterial strains by the fruit and leaf extracts could be due to the presence of antioxidant phytochemicals, mainly polyphenols, in the extracts. The T. ferdinandiana results support several other studies, showing the antimicrobial activity of plant extracts due to the presence of polyphenolic compounds in the extracts [26,43]. Polyphenols, particularly tannins and flavonols, are known to possess antimicrobial activity and can suppress the growth of microorganisms 
by various mechanisms, such as the inhibition of biofilm formation, host-ligand adhesion reduction, and the neutralization of bacterial toxins [44].

In the present study, we found that T. ferdinandiana tissue extracts are high in TPC and tannins. Other species of Terminalia plants, such as Terminalia arjuna, Terminalia bellerica, Terminalia chebula, Terminalia sambesiaca, Terminalia Kaiserana and Terminalia sericia, are also high in tannins and other polyphenols [45-47]. Previous reports on the antimicrobial properties of Terminalia plants were supported by the presence of a vast range of phytochemicals, including polyphenols and tannins [48-50]. Tannins inhibit bacterial growth by binding to bacterial enzymes and interfering with phosphorylation, and sometimes forming complexes with transition metal ions, which are important for bacterial growth [51].

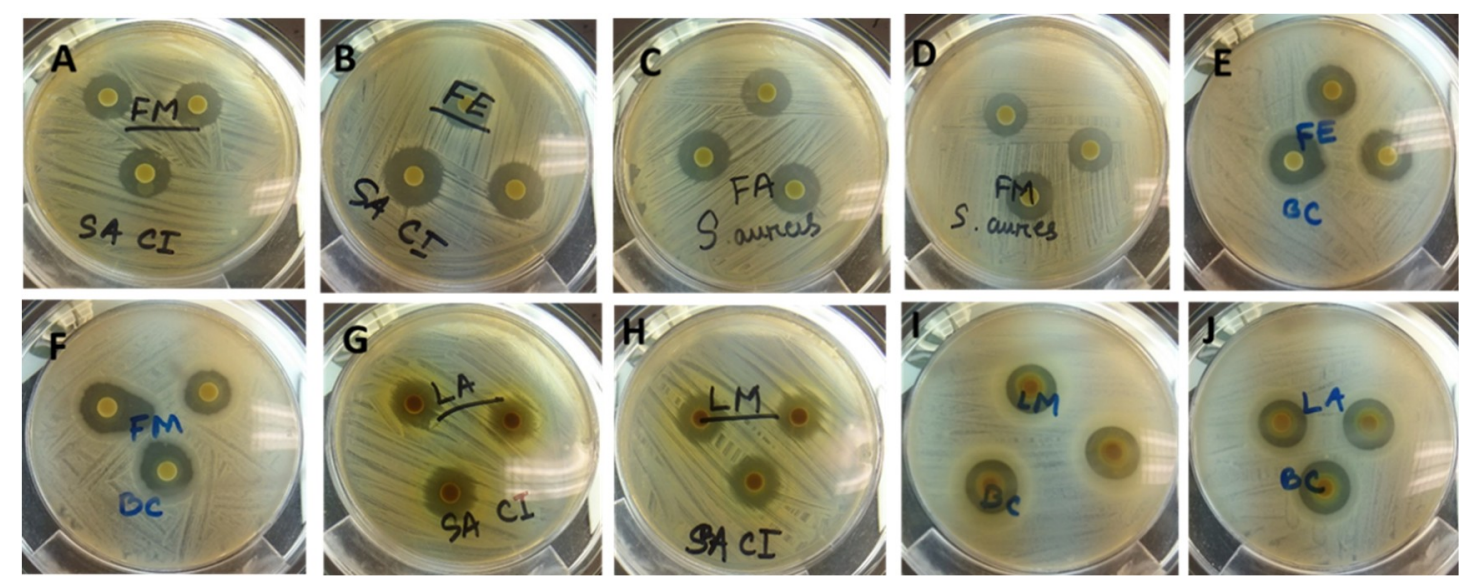

Figure 3. Antimicrobial activity (zones of inhibition) of ASE extracts of T. ferdinandiana tissues against various organisms. FM and FE against MRSA (A and B), FA and FM against Staphylococcus aureus (C and D), FE and FM against Bacillus cereus (E and F), LA and LM against MRSA (G and H), LM and LA against B. cereus (I and J). FM; Fruit methanol extract, FE; Fruit ethanol extract, FA; Fruit acetone extract, LA; Leaf acetone extract, LM; Leaf methanol extract; MRSA; Methicillin resistant Staphylococcus aureus. 
Table 5. Antimicrobial activity of the extracts of T. ferdinandiana tissues.

\begin{tabular}{|c|c|c|c|c|c|c|c|}
\hline \multirow{2}{*}{$\begin{array}{l}\text { ASE Extraction } \\
\text { Solvent }\end{array}$} & \multirow{2}{*}{$\begin{array}{c}\text { T. ferdinandiana } \\
\text { Tissues }\end{array}$} & \multicolumn{6}{|c|}{ Zone of Inhibition (in mm) } \\
\hline & & S. aureus & MRSA & $\begin{array}{c}\text { Pseudomonas } \\
\text { aeruginosa }\end{array}$ & P. aeruginosa $(\mathrm{CI})$ & B. cereus & $\begin{array}{c}\text { Listeria } \\
\text { monocytogenes }\end{array}$ \\
\hline \multirow{4}{*}{ Methanol } & Fruits & $13.8 \pm 0.3^{\mathrm{a}, \mathrm{w}}$ & $16.4 \pm 0.0^{\mathrm{a}, \mathrm{x}}$ & - & $11.2 \pm 0.0^{\mathrm{a}, \mathrm{w}}$ & $16.4 \pm 0.9^{a, x}$ & $20.4 \pm 2.0^{a, y}$ \\
\hline & Leaves & - & $15.2 \pm 0.4^{\mathrm{a}, \mathrm{w}}$ & - & $14.6 \pm 1.5^{\mathrm{b}, \mathrm{w}}$ & $16.0 \pm 0.6^{\mathrm{a}, \mathrm{w}}$ & $21.3 \pm 0.2^{a, x}$ \\
\hline & Seedcoats & - & $8.8 \pm 0.0^{b, w}$ & - & - & $11.5 \pm 0.6^{b, x}$ & $11.4 \pm 0.8^{b, x}$ \\
\hline & Barks & $11.6 \pm 0.4^{\mathrm{a}}$ & $12.0 \pm 0.8^{c}$ & - & - & $12.8 \pm 0.3^{\mathrm{b}}$ & - \\
\hline \multirow{4}{*}{ Water } & Fruits & - & - & - & $12.9 \pm 1.4^{\mathrm{a}}$ & - & - \\
\hline & Leaves & - & $13.3 \pm 1.4^{\mathrm{c}, \mathrm{w}}$ & - & $10.7 \pm 0.8^{a, x}$ & - & - \\
\hline & Seedcoats & - & - & - & - & - & - \\
\hline & Barks & $10.8 \pm 1.4^{\mathrm{a}}$ & $11.6 \pm 0.5^{c}$ & - & - & $11.1 \pm 0.4^{\mathrm{b}}$ & - \\
\hline \multirow{4}{*}{ Ethanol } & Fruits & - & $17.1 \pm 0.1^{\mathrm{a}}$ & - & - & $17.8 \pm 0.6^{\mathrm{a}}$ & $18.5 \pm 0.5^{\mathrm{a}}$ \\
\hline & Leaves & - & $14.6 \pm 0.2^{\mathrm{a}, \mathrm{w}}$ & - & - & $16.5 \pm 1.0^{\mathrm{a}, \mathrm{x}}$ & $20.0 \pm 0.6^{a, y}$ \\
\hline & Seedcoats & - & - & - & - & $9.8 \pm 0.8^{\mathrm{c}}$ & $10.8 \pm 0.6^{\mathrm{b}}$ \\
\hline & Barks & $12.1 \pm 0.3^{\mathrm{a}}$ & $12.7 \pm 0.9^{c}$ & - & - & $13.2 \pm 1.1^{b}$ & - \\
\hline \multirow{4}{*}{ Acetone } & Fruits & $16.7 \pm 0.5^{b, w}$ & $16.6 \pm 0.3^{a, w}$ & - & $13.3 \pm 0.1^{b, x}$ & $18.4 \pm 1.5^{\mathrm{a}, \mathrm{y}}$ & $20.5 \pm 0.4^{\mathrm{a}, \mathrm{z}}$ \\
\hline & Leaves & - & $15.7 \pm 0.9^{a, w}$ & $8.7 \pm 0.8^{\mathrm{a}, \mathrm{x}}$ & $14.1 \pm 0.1^{b, w}$ & $16.1 \pm 0.3^{\mathrm{a}, \mathrm{w}}$ & $21.0 \pm 1.3^{\mathrm{a}, \mathrm{y}}$ \\
\hline & Seedcoats & - & - & - & - & - & - \\
\hline & Barks & $15.0 \pm 1.0^{\mathrm{b}, \mathrm{w}}$ & $11.0 \pm 1.5^{c, x}$ & - & - & $15.7 \pm 0.6^{\mathrm{a}, \mathrm{w}}$ & $15.3 \pm 1.8^{c, w}$ \\
\hline \multicolumn{2}{|c|}{ Oxytetracycline $(0.25 \mathrm{mg} / \mathrm{mL})$} & $33.9 \pm 0.0^{c, w}$ & $29.7 \pm 1.9^{\mathrm{d}, w}$ & $13.8 \pm 0.5^{b, x}$ & $18.1 \pm 0.6^{c, y}$ & $17.3 \pm 1.5^{\mathrm{a}, \mathrm{y}}$ & $33.3 \pm 0.4 \mathrm{~d}, \mathrm{w}$ \\
\hline
\end{tabular}

Results are expressed as mean \pm SD; $(n=3)$. Mean values of each column are significantly different $(p<0.05)$. (-) denotes that no zone of inhibition was observed. Criteria for antimicrobial activity: $<10 \mathrm{~mm}=$ weak, $10-15 \mathrm{~mm}=$ moderate, and $>15 \mathrm{~mm}=$ strong. Mean values of each column with different letters are significantly different $(p<0.05)$. a, b, $\mathrm{c}$, d; denote significant differences of extraction solvents within same tissue. $\mathrm{w}, \mathrm{x}, \mathrm{y}, \mathrm{z}$; denote significant differences of the same extraction solvent across tissues. Controls (reverse osmosis (RO) water and $20 \%$ ethanol) did not show any zone of inhibition. 
3.5.2. Determination of Minimum Inhibitory Concentration (MIC) and Minimum Bactericidal Concentration $(\mathrm{MBC})$

MIC and MBC values of the extracts of T. ferdinandiana tissues against the tested microbial strains are shown in Table 6. In general, the MIC and MBC values of the extracts against the tested microorganisms ranged from $1.0 \mathrm{mg}$ extract $/ \mathrm{mL}$ to $3.0 \mathrm{mg} / \mathrm{mL}$, with L. monocytogenes, B. cereus, and MRSA the most sensitive among the tested microorganisms. Different tissues extracted with different solvents showed variable inhibitory effects. For example, the MIC of S. aureus was $1 \mathrm{mg} / \mathrm{mL}$ against bark ethanol extracts, whereas the MIC in response to bark water extracts was $3 \mathrm{mg} / \mathrm{mL}$. The MIC of P. aeruginosa, P. aeruginosa CI, L. monocytogenes, and B. cereus ranged from 1 to $2 \mathrm{mg} / \mathrm{mL}$ of extracts, however for $S$. aureus and MRSA, $3 \mathrm{mg} / \mathrm{mL}$ was needed for inhibition.

Overall, the ethanol and acetone extracts were the most effective at inhibiting the growth of the microorganisms compared to methanol and water extracts. It is interesting to note that even though the antioxidant capacity and phenolic content of the methanol and water extracts was found to be higher than the ethanol extracts, the acetone extracts showed lower antioxidant capacity and phenolic contents overall. The phytochemicals responsible for antioxidant capacity may not be the only compounds contributing to antimicrobial activity, it is possible that other phytochemicals with antimicrobial potentials are exerting antimicrobial activities.

Table 6. The minimum inhibitory concentration (MIC) and minimum bactericidal concentration (MBC) of the extracts of T. ferdinandiana tissues.

\begin{tabular}{|c|c|c|c|c|c|c|c|c|c|c|c|c|c|c|}
\hline \multirow[t]{2}{*}{ Tested Microorganisms } & \multicolumn{14}{|c|}{$\mathrm{MIC}(\mathrm{mg} / \mathrm{mL})$} \\
\hline & FM & $\mathbf{L M}$ & SM & BM & FW & LW & BW & FE & LE & SE & BE & FA & LA & BA \\
\hline Staphylococcus aureus & 1.5 & & & 2 & & & 3 & & & & 1 & 1 & & 2 \\
\hline MRSA & 3 & 2.5 & & 1 & & & 2.5 & 3 & 3 & & 3 & 3 & & 1 \\
\hline Pseudomonas aeruginosa & 1 & & & & 1 & 1 & & & 1 & & & 1 & & \\
\hline $\begin{array}{c}\text { Pseudomonas aeruginosa } \\
\text { CI }\end{array}$ & & & & & & 1 & & & 1 & & & 1 & & \\
\hline Bacillus cereus & 1.5 & 1 & 1 & 1.5 & & & 1 & 1 & 1 & 1 & 1 & & 1 & 1 \\
\hline \multirow[t]{3}{*}{ Listeria monocytogenes } & 1 & 1 & 1 & & & & & 1 & 2 & 1 & & 1 & & 1 \\
\hline & \multicolumn{14}{|c|}{ MBC (mg/mL) } \\
\hline & FM & LM & SM & BM & FW & LW & BW & $\mathrm{FE}$ & LE & SE & BE & FA & LA & BA \\
\hline Staphylococcus aureus & 1.5 & & & 1 & & & 2 & & & & 1 & 1 & & 2 \\
\hline MRSA & 3 & 3 & & 1 & & & 2 & 2 & 3 & & 2 & 3 & & 1 \\
\hline Pseudomonas aeruginosa & 1 & & & & 1 & 1 & & & 1 & & & 1 & & \\
\hline $\begin{array}{c}\text { Pseudomonas aeruginosa } \\
\text { CI }\end{array}$ & & & & & & 1 & & & 1 & & & 1 & & \\
\hline Bacillus cereus & 1.5 & 1 & 1 & 1 & & & & 1 & 1 & 1 & 1 & & 1 & 1 \\
\hline Listeria monocytogenes & 1 & 1 & 1 & & & & & 1 & 2 & 1 & & 1 & & 1 \\
\hline
\end{tabular}

\subsubsection{Scanning Electron Microscopy}

The antimicrobial effects of T. ferdinandiana fruit and leaf extracts on the morphology of MRSA, B. cereus, L. monocytogenes, and P. aeruginosa CI cells were determined by scanning electron microscopy, as illustrated in Figures 4 and 5. All bacterial cells treated with the extracts at the MIC were damaged compared to the control cells (20\% v/v ethanol). The control cells had a smooth surface, with the outer layer of the bacteria relatively intact (Figure 4A,D and Figure 5A,D). By contrast, the damaging effects of the fruit and leaf extracts on bacterial cell walls were evident compared to the appearance of the control cells (Figure 4B,C,E,F and Figure 5B,C,E,F). Almost all the bacterial cells treated with the fruit and leaf extracts showed the disintegration of the outermost layer and, in some cases, the outermost layer had disappeared (Figures $4 \mathrm{~F}$ and $5 \mathrm{E}, \mathrm{F}$ ). 

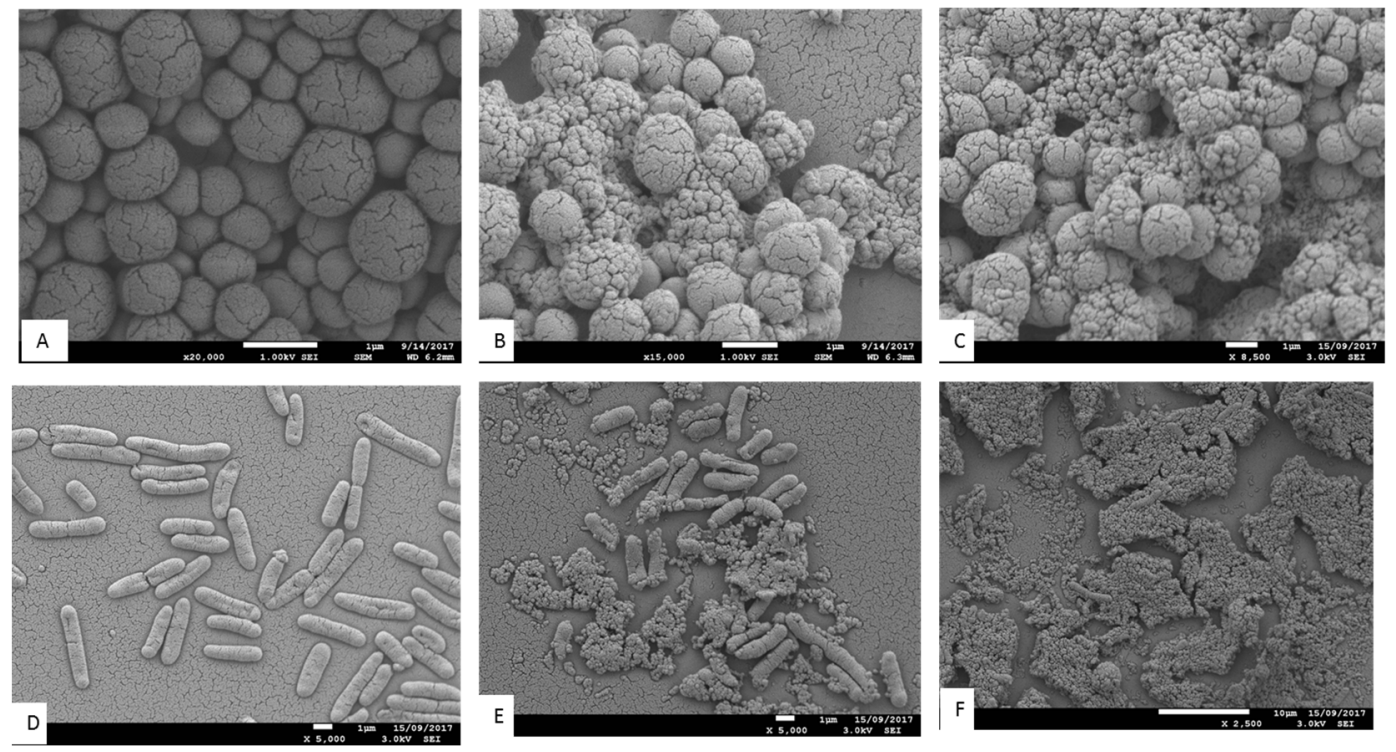

Figure 4. Antimicrobial activity of methanolic ASE of T. ferdinandiana fruits and leaves. Scanning electron microscopy (SEM) images of methicillin resistant Staphylococcus aureus control (A), effect of fruit extracts (B), effect of leaf extracts (C), and clinical isolates of Pseudomonas aeruginosa control (D), effect of fruit extracts (E) and effect of leaf extracts (F). Samples were imaged in a Jeol JSM 7100F field emission SEM at an accelerating voltage of $1 \mathrm{kV}$.
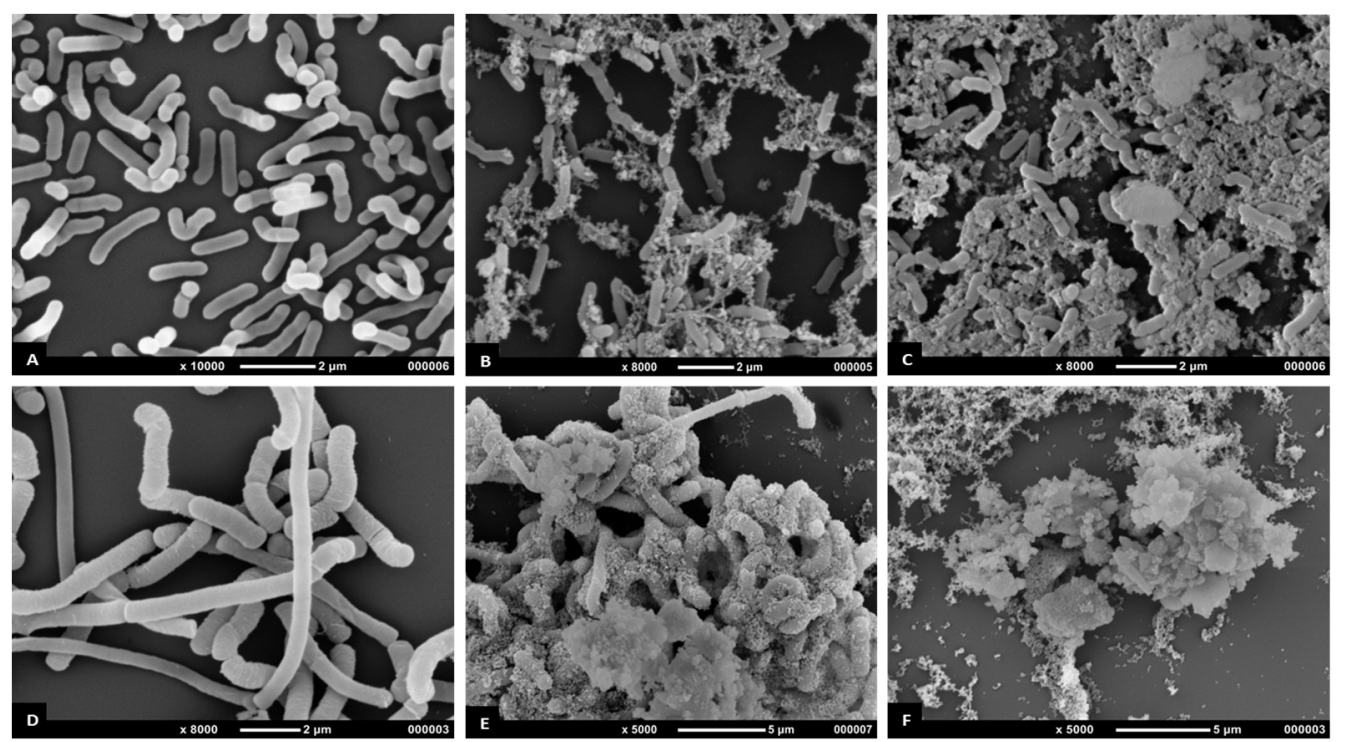

Figure 5. Antimicrobial activity of methanolic ASE of T. ferdinandiana fruits and leaves. SEM images of Listeria monocytogenes treated with control (A), fruit extracts (B), and leaf extracts (C), and Bacillus cereus treated with control (D), fruit extracts (E), and leaf extracts (F). Samples were imaged in a Jeol Neoscope JCM 5000 at an accelerating voltage of $10 \mathrm{kV}$.

The antimicrobial mechanisms or exact target sites for natural antimicrobials have not been identified yet and warrant further investigation [6]. However, it is thought that terpenoids and phenolics are involved in membrane disruption, phenolic acids and flavonoids cause metal chelation, coumarin interferes with the genetic material, and alkaloids inhibit the growth of microorganisms [52]. Phytochemicals are also reported to be involved in membrane disruption and, in turn, cause leakage of cellular content [53]. It was observed that plant phytochemicals interfere with active transport mechanisms and possibly dissipate cellular energy in adenosine triphosphate (ATP) form [54]. 
In Figure 5B,C, some of the extract-treated L. monocytogenes cells underwent splitting, a change in cell morphology due to deep wrinkling and distortion. Therefore, it is postulated that fruit and leave methanol extracts have antimicrobial activity against L. monocytogenes. Antioxidative polyphenols might have been involved in causing lesions in the cytoplasmic membrane, which in turn may have caused leakage of intracellular contents, impairment of microbial enzymes, and potentially cell death [53]. This evidence suggests that $T$. ferdinandiana fruits extracts may effectively inhibit L. monocytogenes in food products.

To visualize the effects of T. ferdinandiana fruit and leaf methanol extracts, SEM images of B. cereus cells treated with MIC doses of extracts were taken and are presented in Figure 5. The fruit and leaf extracts altered the cell morphology (Figure 5E,F) in comparison to controls (Figure 5D). The control bacterial cells appeared whole and distinct from one another, whilst the bacterial cells treated with both the fruit and leaf extracts were deformed. In particular, the cell wall of B. cereus treated with leaf extracts appeared to be degraded (Figure 5F).

A change in cell morphology was observed in P. aeruginosa clinical isolates incubated with T. ferdinandiana fruit and leaf extracts, as shown in Figure 4E and 4F. The cell surface morphology of P. aeruginosa control cells was intact and smooth (Figure 4D) compared to cells incubated with the MIC of T. ferdinandiana fruit extracts, which changed to granular with the appearance of blisters (Figure 4E). Treatment with leaf extracts was even more pronounced, as evidenced by the loss of cellular orientation (Figure 4F). These results suggest that T. ferdinandiana leaf extracts are more active than fruit extracts in promoting $P$. aeruginosa cell death caused by cell membrane disintegration and cell atrophy, indicating that the active compounds present in T. ferdinandiana leaf extracts may act on the cell membrane or extracellular proteins, resulting in the inhibition of bacterial cell growth.

Scanning electron microscopy images of MRSA (Figure 4B,C) treated with $T$. ferdinandiana extracts also showed partial disintegration of the bacterial cell surfaces and reduced residual cellular content. Cell surfaces also appeared rougher after T. ferdinandiana extract treatment. The potent antimicrobial activity observed in the T. ferdinandiana extracts in the present study can therefore be attributed to the presence of numerous phytochemicals in the plant, especially ascorbic and ellagic acid, as previously reported [15]. In the presence of T. ferdinandiana extracts, bacterial cells grew as isolated colonies, compared to control cells. The antimicrobial activity of plants is mostly attributed to their principal phenolic components, which exhibit significant bactericidal activity against MRSA. A reaction between phenolic compounds and bacterial membrane proteins was suggested to be involved in their antimicrobial action, which can weaken the cell wall or damage the cytoplasmic membrane directly [55].

These results indicate that antimicrobial compounds are contained in T. ferdinandiana leaves and fruit and act by damaging bacterial cell walls or inducing cell lysis. It is possible that the antimicrobial compounds present in T. ferdinandiana extracts readily enter the cells through these lesions, whilst also facilitating the leakage of cell contents. That is, when microbial cell walls or membranes become compromised, possibly by interacting with phenolic compounds, low molecular weight substances, such as $\mathrm{K}^{+}$and $\mathrm{PO}_{4}{ }^{3-}$, tend to leach out first, followed by the loss of other intracellular molecules, such as proteins, DNA, RNA, and other higher molecular weight materials [56]. These antimicrobial compounds may even react with bacterial DNA, ultimately resulting in cell death. Some researchers have reported that bioactive compounds derived from plants have antimicrobial effects on cells through reduced oxygen uptake, reduced cellular growth, inhibition of lipid, protein, and nucleic acid synthesis, changes in the lipid profile of the cell membrane, and inhibition of microbial cell wall synthesis. Cox et al. [57] reported that slight changes in the structural integrity of cell membranes can affect cell metabolism and lead to cell death.

A wide variety of phenolic compounds, including tannins, gallic acid, ellagic acid, corilagin, geraniin, tannic acid, punicalagin, castalagin, and punicalin, have been reported to be present in the Terminalia genus [58]. Antimicrobial activity of these compounds has also been reported against a number of microorganisms, such as MRSA, S. aureus, P. aeruginosa, Genus vibrio, Escherichia coli, 
Candida Albicans, and Aspergillus fumigatus [59]. Previous reports on the phytochemicals present in T. ferdinandiana include gallic acid, apionic acid, gluconolactone, chebulic acid, ferulic acid, exifone, corilagin, punicalin, castalagin, and chebulagic acid [14,60]. High levels of ellagic acid and ascorbic acid have also been reported in T. ferdinandiana [15]. T. ferdinandiana fruit is currently marketed commercially as a functional ingredient in the form of a freeze-dried powder in the food industry, however, other tissues such as leaves have not yet been considered as functional (food) ingredients.

\section{Conclusions}

The contamination of food by microorganisms is a worldwide public health problem. To avoid these problems, plant-derived natural preservatives could offer a safer alternative. To date, this is the first study to extensively investigate the antimicrobial properties of $T$. ferdinandiana extracts, revealing that extracts of T. ferdinandiana fruit and leaves possess significant in vitro antimicrobial properties against common foodborne bacteria. The antimicrobial properties of this plant were also supported by the presence of significant antioxidant and tannin contents. Overall, the results of our present study showed that $T$. ferdinandiana fruit and leaves have great potential as natural preservatives in the food industry. However, further research on the bioactive compounds present in T. ferdinandiana extracts is needed to determine the compounds responsible for the antimicrobial properties.

Author Contributions: S.A. performed the experiments; collected, analysed and interpreted the data and drafted the manuscript. S.A.O., Y.S., M.T.F., M.E.N. and U.T. conceived and designed the experiments, checked and approved the results and critically revised the manuscript. All authors read and approved the final version of the manuscript.

Funding: This project was funded by AgriFutures Australia Grant 201430161. Saleha Akter's PhD is supported by an Australian Government Research Training Program Scholarship and The University of Queensland.

Acknowledgments: We gratefully acknowledge the contribution of Kathryn Green at the Centre for Microscopy and Microanalysis, The University of Queensland, for taking the SEM images.

Conflicts of Interest: The authors declare that there is no competing financial, professional or personal interests that might have influenced the performance or presentation of the work described in this manuscript.

\section{References}

1. Hayouni, E.; Abedrabba, M.; Bouix, M.; Hamdi, M. The effects of solvents and extraction method on the phenolic contents and biological activities in vitro of Tunisian Quercus coccifera L. and Juniperus phoenicea L. fruit extracts. Food Chem. 2007, 105, 1126-1134. [CrossRef]

2. Shahidi, F.; Ambigaipalan, P. Phenolics and polyphenolics in foods, beverages and spices: Antioxidant activity and health effects-A review. J. Funct. Foods 2015, 18, 820-897. [CrossRef]

3. Yanishlieva, N.; Marinova, E. Stabilisation of edible oils with natural antioxidants. Eur. J. Lipid Sci. Technol. 2001, 103, 752-767. [CrossRef]

4. Pietta, P. Flavonoids as antioxidants. J. Nat. Prod. 2000, 63, 1035-1042. [CrossRef] [PubMed]

5. Cleveland, J.; Montville, T.; Nes, I.; Chikindas, M. Bacteriocins: Safe, natural antimicrobials for food preservation. Int. J. Food Microbiol. 2001, 71, 1-20. [CrossRef]

6. Negi, P. Plant extracts for the control of bacterial growth: Efficacy, stability and safety issues for food application. Int. J. Food Microbiol. 2012, 156, 7-17. [CrossRef] [PubMed]

7. Tajkarimi, M.; Ibrahim, S.; Cliver, D. Antimicrobial herb and spice compounds in food. Food Control 2010, 21, 1199-1218. [CrossRef]

8. Cunningham, A.; Garnett, S.; Gorman, J.; Courtenay, K.; Boehme, D. Eco-enterprises and Terminalia ferdinandiana: "Best laid plans" and Australian policy lessons. Econ. Bot. 2009, 63, 16-28. [CrossRef]

9. Gorman, J.; Griffiths, A.; Whitehead, P. An analysis of the use of plant products for commerce in remote aboriginal communities of northern Australia. Econ. Bot. 2006, 60, 362-373. [CrossRef]

10. Hegarty, M.; Hegarty, E. Food safety of Australian plant bushfoods. Rural Industr. Res. Develop. Corporat. 2001, 01/28, AGP-1A.

11. Mohanty, S.; Cock, I. The chemotherapeutic potential of Terminalia ferdinandiana: Phytochemistry and bioactivity. Pharmacogn Rev. 2012, 6, 29-36. [PubMed] 
12. Konczak, I.; Maillot, F.; Dalar, A. Phytochemical divergence in 45 accessions of Terminalia ferdinandiana (kakadu plum). Food Chem. 2014, 151, 248-256. [CrossRef] [PubMed]

13. Sultanbawa, Y.; Williams, D.; Smyth, H. Changes in Quality and Bioactivity of Native Food During Storage; Rural Industries Research and Development Corporation (RIRDC): Canberra, Australia, 2015.

14. Courtney, R.; Sirdaarta, J.; Matthews, B.; Cock, I. Tannin components and inhibitory activity of kakadu plum leaf extracts against microbial triggers of autoimmune inflammatory diseases. Pharmacog. J. 2015, 7, 18-31. [CrossRef]

15. Williams, D.; Edwards, D.; Pun, S.; Chaliha, M.; Burren, B.; Tinggi, U.; Sultanbawa, Y. Organic acids in kakadu plum (Terminalia ferdinandiana): The good (ellagic), the bad (oxalic) and the uncertain (ascorbic). Food Res. Int. 2016, 89, 237-244. [CrossRef] [PubMed]

16. Konczak, I.; Zabaras, D.; Dunstan, M.; Aguas, P. Antioxidant capacity and hydrophilic phytochemicals in commercially grown native Australian fruits. Food Chem. 2010, 123, 1048-1054. [CrossRef]

17. Akter, S.; Netzel, M.E.; Fletcher, M.T.; Tinggi, U.; Sultanbawa, Y. Chemical and nutritional composition of Terminalia ferdinandiana (kakadu plum) kernels: A novel nutrition source. Foods 2018, 7, 60. [CrossRef] [PubMed]

18. Navarro, M.; Stanley, R.; Cusack, A.; Yasmina, S. Combinations of plant-derived compounds against campylobacter in vitro. J. Appl. Poul. Res. 2015, 24, 352-363. [CrossRef]

19. Al-Asmari, F.; Nirmal, N.; Chaliha, M.; Williams, D.; Mereddy, R.; Shelat, K.; Sultanbawa, Y. Physico-chemical characteristics and fungal profile of four saudi fresh date (Phoenix dactylifera 1.) cultivars. Food Chem. 2017, 221, 644-649. [CrossRef]

20. Musa, K.; Abdullah, A.; Kuswandi, B.; Hidayat, M. A novel high throughput method based on the dpph dry reagent array for determination of antioxidant activity. Food Chem. 2013, 141, 4102-4106. [CrossRef]

21. Xi, M.; Hai, C.; Tang, H.; Chen, M.; Fang, K.; Liang, X. Antioxidant and antiglycation properties of total saponins extracted from traditional Chinese medicine used to treat diabetes mellitus. Phytother. Res. 2008, 22, 228-237. [CrossRef]

22. Ahmed, A.; McGaw, L.; Moodley, N.; Naidoo, V.; Eloff, J. Cytotoxic, antimicrobial, antioxidant, antilipoxygenase activities and phenolic composition of Ozoroa and Searsia species (Anacardiaceae) used in south African traditional medicine for treating diarrhoea. South Afr. J. Bot. 2014, 95, 9-18. [CrossRef]

23. Hoang, V.; Pierson, J.; Curry, M.; Shaw, P.; Dietzgen, R.; Gidley, M.; Thomson, S.; Monteith, G. Polyphenolic contents and the effects of methanol extracts from mango varieties on breast cancer cells. Food Sci. Biotechnol. 2015, 24, 265-271. [CrossRef]

24. Dussault, D.; Vu, K.; Lacroix, M. In vitro evaluation of antimicrobial activities of various commercial essential oils, oleoresin and pure compounds against food pathogens and application in ham. Meat Sci. 2014, 96, 514-520. [CrossRef] [PubMed]

25. Sultanbawa, Y.; Cusack, A.; Currie, M.; Davis, C. An innovative microplate assay to facilitate the detection of antimicrobial activity in plant extracts. J. Rapid Methods Autom. Microbiol. 2009, 17, 519-534. [CrossRef]

26. Shami, A.; Philip, K.; Muniandy, S. Synergy of antibacterial and antioxidant activities from crude extracts and peptides of selected plant mixture. BMC Complement. Alter. Med. 2013, 13, 360. [CrossRef] [PubMed]

27. Alderees, F.; Mereddy, R.; Webber, D.; Nirmal, N.; Sultanbawa, Y. Mechanism of action against food spoilage yeasts and bioactivity of Tasmannia lanceolata, Backhousia citriodora and Syzygium anisatum plant solvent extracts. Foods 2018, 7, 179. [CrossRef]

28. Naczk, M.; Shahidi, F. Phenolics in cereals, fruits and vegetables: Occurrence, extraction and analysis. J. Pharm. Biomed. Anal. 2006, 41, 1523-1542. [CrossRef]

29. Ahmed, A.; McGaw, L.; Eloff, J. Evaluation of pharmacological activities, cytotoxicity and phenolic composition of four maytenus species used in southern african traditional medicine to treat intestinal infections and diarrhoeal diseases. BMC Complement. Altern. Med. 2013, 13, 100. [CrossRef]

30. Ahmed, A.; Elgorashi, E.; Moodley, N.; McGaw, L.; Naidoo, V.; Eloff, J. The antimicrobial, antioxidative, anti-inflammatory activity and cytotoxicity of different fractions of four south African Bauhinia species used traditionally to treat diarrhoea. J. Ethnopharmacol. 2012, 143, 826-839. [CrossRef]

31. Ye, C.; Dai, D.; Hu, W. Antimicrobial and antioxidant activities of the essential oil from onion (Allium cepa L.). Food Control 2013, 30, 48-53. [CrossRef]

32. Harborne, J.; Baxter, H.; Moss, G.P. Phytochemical Dictionary: Handbook of Bioactive Compounds from Plants, 2nd ed.; Taylor \& Francis: London, UK, 1999. 
33. Nickel, J.; Spanier, L.; Botelho, F.; Gularte, M.; Helbig, M. Characterization of betalains, saponins and antioxidant power in differently colored quinoa (Chenopodium quinoa) varieties. Food Chem. 2017, 234, 285-294.

34. Ruiz, K.; Khakimov, B.; Engelsen, S.; Bak, S.; Biondi, S.; Jacobsen, S. Quinoa seed coats as an expanding and sustainable source of bioactive compounds: An investigation of genotypic diversity in saponin profiles. Indust. Crops Prod. 2017, 104, 156-163. [CrossRef]

35. Price, K.; Johnson, I.; Fenwick, G.; Malinow, M. The chemistry and biological significance of saponins in foods and feedingstuffs. C R C Crit. Rev. Food Sci. Nutr. 1987, 26, 27-135. [CrossRef]

36. Lásztity, R.; Hidvégi, M.; Bata, Á. Saponins in food. Food Rev. Int. 1998, 14, 371-390. [CrossRef]

37. Fenwick, D.; Oakenfull, D. Saponin content of food plants and some prepared foods. J. Sci. Food Agric. 1983, 34, 186-191. [CrossRef]

38. Hartzfeld, P.; Forkner, R.; Hunter, M.; Hagerman, A. Determination of hydrolyzable tannins (gallotannins and ellagitannins) after reaction with potassium iodate. J. Agric. Food Chem. 2002, 50, 1785-1790. [CrossRef]

39. Koleckar, V.; Kubikova, K.; Rehakova, Z.; Kuca, K.; Jun, D.; Jahodar, L.; Opletal, L. Condensed and hydrolysable tannins as antioxidants influencing the health. Mini Rev. Med. Chem. 2008, 8, 436-447. [CrossRef]

40. Smeriglio, A.; Barreca, D.; Bellocco, E.; Trombetta, D. Proanthocyanidins and hydrolysable tannins: Occurrence, dietary intake and pharmacological effects. Br. J. Pharmacol. 2017, 174, 1244-1262. [CrossRef]

41. Balogun, A.; Fetuga, B. Tannin, phytin and oxalate contents of some wild under-utilized crop-seeds in Nigeria. Food Chem. 1988, 30, 37-43. [CrossRef]

42. Humeera, N.; Kamili, A.; Bandh, S.; Amin, S.; Lone, B.; Gousia, N. Antimicrobial and antioxidant activities of alcoholic extracts of Rumex dentatus L. Microb. Pathog. 2013, 57, 17-20. [CrossRef]

43. Cock, I.; Mohanty, S. Evaluation of the antibacterial activity and toxicity of Terminalia ferdinandiana fruit extracts. Pharmacog. J. 2011, 3, 72-79. [CrossRef]

44. Daglia, M. Polyphenols as antimicrobial agents. Curr. Opin. Biotechnol. 2012, 23, 174-181. [CrossRef] [PubMed]

45. Pfundstein, B.; Desouky, S.; Hull, W.; Haubner, R.; Erben, G.; Owen, R. Polyphenolic compounds in the fruits of Egyptian medicinal plants (Terminalia bellerica, Terminalia chebula and Terminalia horrida): Characterization, quantitation and determination of antioxidant capacities. Phytochemistry 2010, 71, 1132-1148. [CrossRef] [PubMed]

46. Chakraborty, S.; Mitra, M.K.; Chaudhuri, M.G.; Sa, B.; Das, S.; Dey, R. Study of the release mechanism of Terminalia chebula extract from nanoporous silica gel. Appl. Biochem. Biotechnol. 2012, 168, 2043-2056. [CrossRef] [PubMed]

47. Dhanani, T.; Shah, S.; Kumar, S. A validated high-performance liquid chromatography method for determination of tannin-related marker constituents gallic acid, corilagin, chebulagic acid, ellagic acid and chebulinic acid in four Terminalia species from India. J. Chromatogr. Sci. 2015, 53, 625-632. [CrossRef] [PubMed]

48. Abiodun, O.; Sood, S.; Osiyemi, O.; Agnihotri, V.; Gulati, A.; Ajaiyeoba, E.; Singh, B. In vitro antimicrobial activity of crude ethanol extracts and fractions of Terminalia catappa and Vitex doniana. Afr. J. Med. Med. Sci. 2015, 44, 21-26. [PubMed]

49. Sivakumar, V.; Mohan, R.; Rangasamy, T.; Muralidharan, C. Antimicrobial activity of myrobalan (Terminalia chebula retz.) nuts: Application in raw skin preservation for leather making. Ind. J. Nat. Prod. Res. 2016, 7 , 65-68.

50. Mandal, S.; Patra, A.; Samanta, A.; Roy, S.; Mandal, A.; Mahapatra, T.D.; Pradhan, S.; Das, K.; Nandi, D.K. Analysis of phytochemical profile of Terminalia arjuna bark extract with antioxidative and antimicrobial properties. Asian Pac. J. Trop. Biomed. 2013, 3, 960-966. [CrossRef]

51. Macáková, K.; Kolečkář, V.; Cahlíková, L.; Chlebek, J.; Hošt’álková, A.; Kuča, K.; Jun, D.; Opletal, L. Chapter 6-Tannins and their influence on health. In Recent Advances in Medicinal Chemistry; Rahman, A., Choudhary, M., Perry, G., Eds.; Elsevier: Amsterdam, The Netherlands, 2014; Volume 1, pp. 159-208.

52. Cowan, M. Plant products as antimicrobial agents. Clin. Microbiol. Rev. 1999, 12, 564-582. [CrossRef] [PubMed] 
53. Lv, F.; Liang, H.; Yuan, Q.; Li, C. In vitro antimicrobial effects and mechanism of action of selected plant essential oil combinations against four food-related microorganisms. Food Res. Int. 2011, 44, 3057-3064. [CrossRef]

54. Davidson, P.; Taylor, T. Chemical preservatives and natural antimicrobial compounds. In Food Microbiology: Fundamentals and Frontiers, 3rd ed.; American Society of Microbiology: Washington, DC, USA, 2007.

55. Eom, S.; Lee, D.; Jung, Y.; Park, J.; Choi, J.; Yim, M.; Jeon, J.; Kim, H.; Son, K.; Je, J.; et al. The mechanism of antibacterial activity of phlorofucofuroeckol-A against methicillin-resistant Staphylococcus aureus. Appl. Microbiol. Biotechnol. 2014, 98, 9795-9804. [CrossRef]

56. Su, X.; Howell, A.; D'Souza, D. Antibacterial effects of plant-derived extracts on methicillin-resistant Staphylococcus aureus. Foodborne Pathog. Dis. 2012, 9, 573-578. [CrossRef]

57. Cox, S.; Mann, C.; Markham, J.; Gustafson, J.; Warmington, J.; Wyllie, G. Determining the antimicrobial actions of tea tree oil. Molecules 2001, 6, 87-91. [CrossRef]

58. Fahmy, N.; Sayed, E.; Singab, A. Genus Terminalia: A phytochemical and biological review. Med. Arom. Plants 2015, 4, 1-22.

59. Ekambaram, S.; Perumal, S.; Balakrishnan, A. Scope of hydrolysable tannins as possible antimicrobial agent. Phytother. Res. 2016, 30, 1035-1045. [CrossRef]

60. Rayan, P.; Matthews, B.; McDonnell, P.; Cock, I. Terminalia ferdinandiana extracts as inhibitors of Giardia duodenalis proliferation: A new treatment for giardiasis. Parasitol. Res. 2015, 114, 2611-2620. [CrossRef]

(C) 2019 by the authors. Licensee MDPI, Basel, Switzerland. This article is an open access article distributed under the terms and conditions of the Creative Commons Attribution (CC BY) license (http://creativecommons.org/licenses/by/4.0/). 